\title{
MINERAL RESOURCE POTENTIAL OF THE PECOS WILDERNESS, SANTA FE, SAN MIGUEL, MORA, RIO ARRIBA, AND TAOS COUNTIES, NEW MEXICO
}

\author{
By \\ Robert H. Moench, U.S. Geological Survey \\ Michael E. Lane, U.S. Bureau of Mines
}

\section{STUDIES RELATED TO WILDERNESS}

Under provisions of the Wilderness Act (Public Law 88-577, September $\hat{i}$, 1964) and the Joint Conference Report on Senate Bill 4, 88th Congress, the U.S. Geological Survey and the U.S. Bureau of Mines have been conducting mineral surveys of wilderness and primitive areas. Areas officially designated as "wilderness," "wild," or "canoe" when the act was passed were incorporated into the National Wilderness Preservation System, and some of them are presently being studied. The act provides that areas under consideration for wilderness designation should be studied for suitability for incorporation into the Wilderness System. The mineral surveys constitute cne aspect of the suitability studies. The act directs that the results of such surveys are to be made available to the public and be submitted to the President and the Congress. This report discusses the results of a minera] survey of the Pecos Wilderness, Santa Fe and Carson National Forests, Sante $\mathrm{Fe}$, San Miguel, Mora, Rio Arriba, and Taos Counties, New Mexico. The nucle'ss of the Pecos Wilderness was established when the Wilderness Act was passed in 1964. Additional adjacent areas were classified as Further Planning and Wilderness during the Second Roadless Area Review and Evaluation (RARE II) by the U.S. Forest Service, January 1979, and some of these were incorporated into the Pecos Wilderness by the New Mexico Wilderness Bill. 


\section{MINERAL RESOURCE POTENTIAL SUMMARY STATEMENT}

A geological and geochemical investigation and a survey of mines, quarries, and prospects have been conducted to evaluate the mineral resource potential of the Pecos Wilderness, Santa Fe, San Miguel, Mora, Rio Arriba, and Taos Counties, N. Mex. The study area covers approximately $348 \mathrm{sq}$ mi at the southern end of the Sangre de Cristo Range. The area is underlain by metamorphic and igneous rocks of Proterozoic age that are partly covered, east of a major north-trending ancient fault, by subhorizontal sedimentary strata of Mississippian, Pennsylvanian, and Permian age. All surface and mineral rights are federally owned.

Although the Pecos mine, which was a major producer of base and precious metals, is within $1.5 \mathrm{mi}$ of the boundary of the Pecos Wilderness, slight1y less than 1 percent of the wilderness has identified mineral resource potentia1.

Moderate resource potential for copper, lead, zinc, gold, and silver in stratabound massive-sulfide deposits of the type developed at the Pecos mine is assigned to about $1 \mathrm{sq} \mathrm{mi} \mathrm{(area} \mathrm{1A)} \mathrm{within} \mathrm{the} \mathrm{wilderness} \mathrm{northwest} \mathrm{of} \mathrm{the}$ Pecos mine. This area is at the northern tip of a 10-sq-mi area of high (area $1 \mathrm{~B}$ ) and moderate (areas $1 \mathrm{~A}$ and 2) mineral resource potential that is south of the wilderness. Area 1B includes the Pecos and Jones mines and the site of a major discovery by Conoco in 1978. In the eastern part of the wilderness, moderate potential for copper, lead, zinc, gold, and silver in massive-sulfide deposits is assigned to a 1/2-sq-mi area in Hollinger Canyon (area 3 ), and to an area of about $1 / 4 \mathrm{sq}$ mi just east of Spring Mountain (area 4 ).

In and near Dalton Canyon, about $7 \mathrm{mi}$ east of Santa Fe and $2 \mathrm{mi}$ south of the wilderness boundary, the Dalton volcanic center (area 5) has high potential for copper, lead, zinc, gold, and silver in massive-sulfide deposits, and for tungsten in stratabound deposits and possible crosscutting veins and pods. An area (area 6) south of the Dalton volcanic center has high potential for the occurrence of tungsten in possible stratabound deposits and (or) crosscutting veins and pods, and farther south is an area (area 7) that has moderate potential for the occurrence of tungsten and molybdenum in similar deposits. This geologic terrane, however, does not extend into the Pecos Wilderness.

Two areas at opposite corners of the study area (both area 8), one in the southeastern part and one near Cordova in the northwestern part, have moderate potential for mica in pegmatite. Another small area near Cordova (area 9) has moderate potential for beryllium in pegmatite.

Small Proterozoic pegmatite dikes and lenses containing lithium-bearing mica (lepidolite) and minor amounts of tantalum have been mined at the Pidlite mine east of the wilderness. A surrounding area of about $11 / 2 \mathrm{sq} \mathrm{mi}$ (area 10) that overlaps about $1 \mathrm{sq} \mathrm{mi}$ of the wilderness has moderate potential for lithium and possibly for tantalum in similar bodies.

Deposits containing zinc, niobium, antimony, minor beryllium, and possibly uranium might occur in brecciated Proterozoic quartzite in an area of about $1 / 2 \mathrm{sq} \mathrm{mi} \mathrm{(area} \mathrm{11)} \mathrm{along} \mathrm{and} \mathrm{near} \mathrm{the} \mathrm{Jicarilla} \mathrm{fault,} \mathrm{east} \mathrm{of} \mathrm{the}$ Truchas Peaks. Similar deposits containing niobium and minor antimony might also occur in an area of about $1 / 2 \mathrm{sq} \mathrm{mi}$ (area 12) about $4 \mathrm{mi}$ to the northwest. These areas are identified as having unknown potential for these commodities on the basis of geochemical data and possibly favorable geologic settings. 
The geochemical data suggest that Proterozoic biotite granite and the quartz porphyry and aphanite unit exposed south of the wilderness (area 13) are chemically specialized types commonly associated with tin-producing districts. If this suggestion is confirmed, these rocks may host greisen or disseminations of tin, thorium, niobium, and possibly tungsten and molybdenum. The most favorable setting for such deposits is the contact zone between stratified metamorphic rocks of the McClure septum and quartz porphyry and aphanite at the southern edge of the Santa Fe Baldy batholith. Although the same granite extends into the wilderness, the data suggest that such deposits, if they exist, are to the south.

With the possible exception of uranium along the Jicarilla fault, there is no potential within the Pecos Wilderness for energy-related commodities, such as coal, oil, gas, or geothermal energy.

\section{INTRODUCTION}

The Pecos Wilderness covers approximately $348 \mathrm{sq} \mathrm{mi}$ at the southern end of the Sangre de Cristo Range in north-central New Mexico, the southernmost major range of the Rocky Mountains. The valley of Rio Grande lies to the west, and to the east is the Great Plain province. The area lies just northeast of the city of Santa $\mathrm{Fe}$, and is reached easily by roads that lead from Interstate 25 on the east and south, from U.S. Highway 285 on the west, and from New Mexico Routes 3, 121, and 76 on the north (fig. 1). Many well maintained hiking and pack trails extend into the interior of the wilderness. The investigated area includes the Pecos Wilderness and approximately $150 \mathrm{sq}$ mi of adjacent territory covering several RARE II Roadless Areas that were excluded from the wilderness by the New Mexico Wilderness Bill. For the purpose of this report, the entire area is called the study area.

The geologic and geochemical studies and the investigations of mines and prospects were done principally in 1977 and 1979-80 (U.S. Geological Survey, U.S. Bureau of Mines, and New Mexico Bureau of Mines and Mineral Resources, 1980 , p. 1-6; Moench and Robertson, 1980; Moench, Robertson, and Sutley, 1980; Moench and Erickson, 1980; Lane, 1980; Erickson and others, 1986; Moench, Grambling and Robertson, 1988; and Moench, Sutley, and Erickson, 1988).

An aeromagnetic survey covering almost all of the Pecos Wilderness was flown in 1970. The resulting aeromagnetic map was interpreted by Lindreth Cordell in Moench, Robertson, and Sutley (1980). Cordell recognized no correlation between aeromagnetic features and geologic terranes having mineral resource potential.

The assessment of mineral resources that is summarized in this report is based principally on an integration of the results of geologic mapping, the occurrence of known mineral deposits, and the geochemical data. Areas having mineral potential are shown on figure 2 .

\section{GEOLOGY}

The study area is underlain by igneous and metamorphic rocks of Proterozoic age that are partly covered east of the Pecos-Picuris fault by subhorizontal sedimentary strata of Mississippian, Pennsylvanian, and Permian age (fig. 2). By far the most important mineral resources of the study area are associated with the stratified metamorphic rocks, which were the focus of this investigation. 


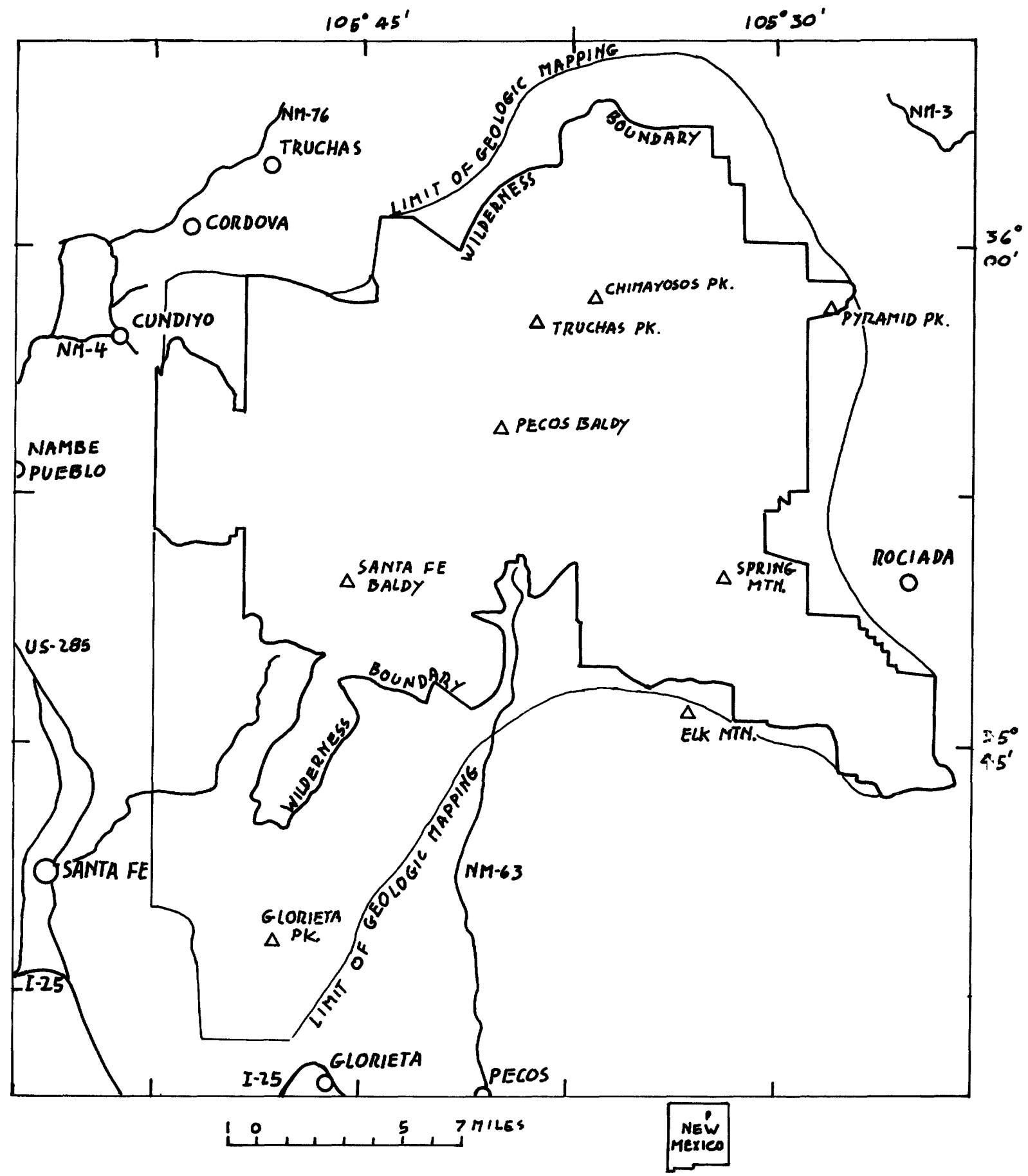

Figure 1.--Map showing location of the Pecos Wilderness and nearby areas, Santa Fe, San Miguel, Rio Arriba, and Taos Counties, New Mexico 


\section{Proterozoic metamorphic rocks}

Rocks east of the Pecos-Picuris fault

East of the Pecos-Picuris fault, stratified metamorphic rocks are broadly separable into a largely metasedimentary quartzite-schist terrane, which underlies the northern quarter of the study area, and the Pecos greenstone belt farther south. The greenstone belt is composed of metamorphosed volcanic and related sedimentary rocks and inferred subvolcanic intrusive igneous rocks (Robertson and Moench, 1979). Rocks of the Pecos greenstone belt lie stratigraphically below rocks of the quartzite-schist terrane and have been dated at about 1,720 Ma (Bowring and Condie, 1982).

The Pecos greenstone belt is host to the Pecos mine, less than $1.5 \mathrm{mi}$ outside the wilderness, which is developed on an important stratabound volcanogenic massive-sulfide deposit that yielded 2.3 million tons of ore containing copper, lead, zinc, gold, and silver. The Jones mine, about $4 \mathrm{mi}$ southwest of the Pecos mine, is developed on a similar type of deposit; an important massive-sulfide deposit was discovered by Conoco near the Jones mine (Mining World, 1978). These deposits are closely related to metamorphosed vent-facies rhyolite that define, along with other associated metavolcanic and metasedimentary rocks, the Pecos volcanic center (Riesmeyer, 1978; Riesmeyer and Robertson, 1979). Because of their obvious economic importance, the geologic investigation was focused on the search for similar ancient volcanic centers, but none was found east of the Pecos-Picuris fault.

Rocks west of the Pecos-Picuris fault

Metamorphic rocks of the western terrane are best exposed in the McClure septum, which lies south of the wilderness between the Santa Fe Baldy and Shaggy Peak batholiths. Rocks of the septum are complexly interstratified metavolcanic and related metasedimentary rocks that lie above quartzite and schist, contrary to relationships observed east of the Pecos-Picuris fault. On the assumption that the quartzite and schist of the McClure septum are approximately equivalent to similar rocks of the quartzite-schist terrane east of the Pecos-Picuris fault, metavolcanic rocks of the septum are distinctly younger than those of the Pecos greenstone belt, in accord with available isotopic dating. According to Fulp (1982), metarhyolite of the septum is comagmatic with nearby quartz porphyry that has been dated at $1,650 \pm 10 \mathrm{Ma}$ (date by S.A. Bowring, U-Pb zircon method, in Fulp, 1982).

A complex assemblage of metamorphosed vent-facies rhyolite and other rocks exposed in Dalton Canyon, at the northeast end of the McClure septum, define the Dalton volcanic center (Fulp, 1982; Moench and Erickson, 1980). The Dalton center shows geochemical and bedrock evidence of base and precious metals that might occur in massive sulfides similar to those of the Pecos volcanic center; the data suggest that the deposits, if they occur, will be richer in copper and silver than ore from the Pecos mine. Unlike the Pecos center, however, the Dalton center is central to a major geochemical tungsten anomaly (Moench and Erickson, 1980; Moench, Sutley, and Erickson, 1988). Moench and Erickson (1980) suggested that the tungsten might occur in scheelite-bearing, stratabound deposits, and one deposit of this type was subsequently discovered by Santa Fe Mining (Fulp and Renshaw, 1985) at or near the site of scheelite-bearing float reported by Moench and Erickson (1980, fig. 1). Fulp and Renshaw (1985) also report the occurrence of many crosscutting, scheelite-bearing veins and pods south of Dalton Canyon. 


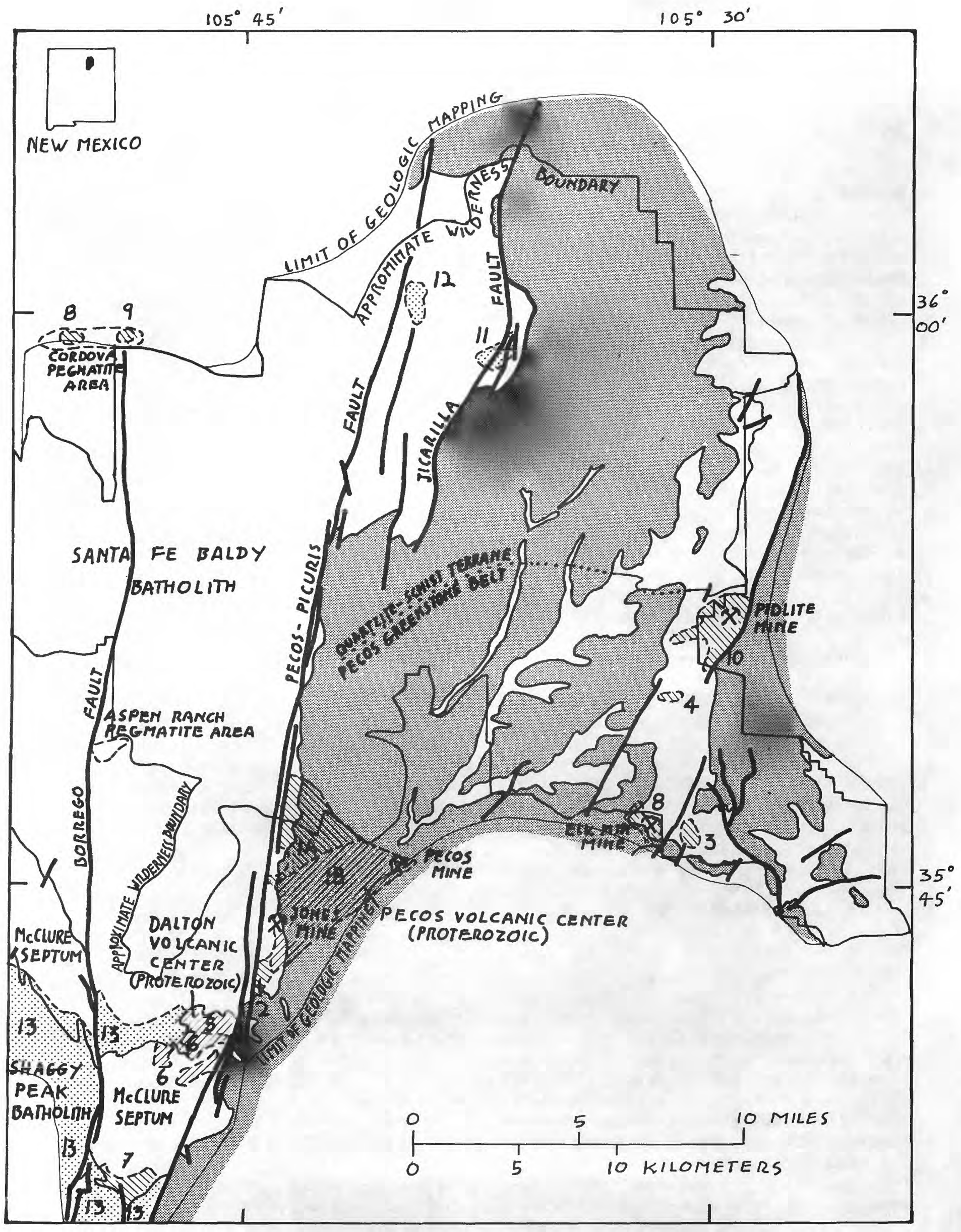




\section{EXPLANATION}

Upper Paleozoic sedimentary rocks

Proterozoic metamorphic and plutonic igneous rocks

Contact

Fault

$x$ Mine

High mineral resource potential--Geologic terrane having past production, or geochemical and exposed evidence of important mineralization associated with rocks characteristic of those having known mineral deposits

$1 \mathrm{~B}, 5$

6

Copper, lead, zinc, gold, and silver in stratabound massivesulfide deposits

Tungsten in possible stratabound deposits and (or) crosscutting veins and pods

5

Tungsten in stratabound deposits and possible crosscutting veins and pods

Moderate mineral resource potential--Geologic terrane containing rock bodies, such as pegmatites, that have been mined in the past but may not be minable in the future; or geologic terrane showing high abundances of two or more mineral resources or geochemical "pathfinder" elements, and a moderately favorable setting for occurrence of mineral deposits

$1 \mathrm{~A}, 2,3,4$

7

8

9

10

Copper, lead, zinc, gold, silver in stratabound massivesulfide deposits

Tungsten and molybdenum in possible stratabound deposits and (or) crosscutting veins and pods

Mica in pegmatite

Beryllium in pegmatite

Lithium and possibly tantalum in pegmatite

Unknown mineral resource potential--Geologic terrane that might contain one or more mineral resources in deposits of types consistent with geologic setting. Although no occurrences of such deposits are known in bedrock, attention is directed to area on basis of geochemical data and geologic favorability

11

Zinc, niobium, antimony, minor beryllium, and possibly uranium in brecciated quartzite

12

13

Niobium and antimony in brecciated quartzite

Tin, thorium, niobium, and possibly tungsten and molybdenum in disseminated deposits or greisen veins related to biotite granite

Figure 2 (Above and facing page).--Map showing mineral resources of the Pecos Wilderness and nearby areas. Geology simplified from Moench, Grambling, and Robertson (1988) 
Although the Pecos and Dalton volcanic centers are closely juxtaposed across the Pecos-Picuris fault, they appear to be unrelated. Prior to Proterozoic faulting, the Dalton and Pecos volcanic centers probably were about $23 \mathrm{mi}$ apart.

\section{Proterozoic plutonic rocks}

In addition to the 1,720-million-year-old metamorphosed gabbro, diabase, tonalite, trondhjemite, and sparse granodiorite and ultramafic rocks that are included in the Pecos greenstone belt, plutonic rocks of the study area include metamorphically foliated quartz diorite, biotite granite, quartz porphyry and aphanite, and syenite and aphanite (all probably about 1,650 m.y. old) and unfoliated two-mica granite and pegmatite (both possibly about 1,450

m.y. old). Quartz diorite is the oldest rock of the Santa Fe Baldy batholith; it is intruded by biotite granite which grades, near the inferred top of the batholith, to quartz porphyry. The quartz porphyry has been dated at $1,650 \pm 10$ $\mathrm{Ma}$ and is thought to be comagmatic with metarhyolite of the McClure septum (Fulp, 1982). Biotite granite also occurs in the Shaggy Peak batholith and the Rio Mora pluton, which also contains quartz porphyry. The syenite and melasyenite occur in a thin, north-trending sheet near the eastern side of the study area. The Hermit Peak pluton, at the southeast corner of the study area, is the largest mapped body of two-mica granite. Two-mica granite also is abundant in the Santa Fe Baldy batholith and associated septa. Pegmatite, probably mainly related to two-mica granite, is widely distributed in the study area.

The geochemical data suggest that biotite granite near the Mcclure septum, south of the Pecos Wilderness, may be similar to specialized granites characteristic of tin-producing districts elsewhere. Further study is necessary, however, to document this suggestion.

The best known mineral resources in the plutonic rocks are in pegmatites, developed for mica, beryl, lithium, and tantalum. The pegmatites occur as small dikes or lenses. Most are unzoned and contain little more than quartz, feldspar, and mica, but a few are complexly zoned and contain a wide variety of rare minerals. The Pidlite pegmatite mine, just east of the wilderness, has produced a small amount of lithium and it contains subeconomic amounts of tantalum (Sheffer and Goldsmith, 1969). Other pegmatites have yielded mica and, locally, beryl. Pegmatites abound in large parts of the Pecos Wilderness, but they were not investigated because in general they are small and low grade. Despite the rare metals or minerals they may contain, the economics of mining generally decreases rapidly as the difficulty of access increases.

\section{Paleozoic sedimentary rocks}

In ascending order, Paleozoic rocks include $200 \mathrm{ft}$ or less of Mississippian marine carbonate and clastic rocks (Espiritu Santo and Tererro Formations), about 3,000 ft of Pennsylvanian marine shale, sandstone, conglomerate, and limestone (Sandia and Madera Formations), and probably several hundred feet of Permian continental red beds (Sangre de Cristo Formation). The geochemical data suggest that the upper Paleozoic sedimentary strata have high background amounts of zinc, copper, and molybdenum and indicate need for further study. 
Structure and mineralized rock

Most of the faults of the study area show little or no evidence of mineralized rock. The geochemical data suggest that parts of the JicariJ.la fault may be an exception, because high abundances of zinc, niobium, ant:mony, and beryllium were detected in heavy-mineral concentrates obtained from streams draining the fault in a small area east of the Truchas Peaks. Tre metalliferous area occurs where Proterozoic quartzite forms both walls of the fault and subsidiary fractures. High abundances of radon that were detected in springs and streams in this area suggest that uranium may be present as we11. High abundances of niobium and antimony also were detected in a $s$ mal1 area underlain by Proterozoic quartzite about $4 \mathrm{mi}$ farther northwest, just east of the Pecos-Picuris fault.

\section{GEOCHEMISTRY}

Geochemical sampling was done in accord with the result of a pilot $s$ tudy carried out in September 1976 by Wallace R. Griffitts, U.S. Geological Survey. The complete results of the geochemical survey are reported in Erickson, Sutler, and Moench (1986) and are summarized in Moench, Sutley, and Erickson (1988).

During this investigation approximately 550 panned concentrates of ravy minerals were obtained from active and intermittent streams that drain al 1 parts of the Pecos Wilderness and the roadless areas that were not incluced in the currently established wilderness. The nonmagnetic and magnetic heavymineral fractions were analyzed spectrographically for 30 elements. Altrough all analyses proved useful, the data for the nonmagnetic fractions provided the mainstay of the geochemical survey.

In addition to this work, stream sediments were collected at selected localities in the wilderness and routinely south of the wilderness in the area of the McClure septum. The minus-80-mesh fraction of all samples was anclyzed spectrographically, and most samples were analyzed for cold-acid extractable copper and citrate-soluble total heavy metals.

The geochemical data delineate a major tungsten anomaly that coincices with Proterozoic metavolcanic rocks of the McClure septum, which contains known scheelite deposits (Moench and Erickson, 1980; Fulp and Renshaw, 1985). This anomaly overlaps a second anomaly defined by high abundances of copper, lead, zinc, gold, silver, and bismuth that coincides with the Dalton volcanic center in the septum, a recognized favorable setting for the occurrence of volcanogenic sulfide deposits.

High or moderately high abundances of the same metals appear to be related to vent-facies and transition-facies metavolcanic rocks of the Penos volcanic center and nearby, in Macho Canyon and Doctor Creek, and with ore small area of transition-facies rocks in Hollinger Canyon. With the possible exception of high abundances of tin and tungsten in Macho Canyon, which ray be related to mineral deposits west of the Pecos-Picuris fault, these metals do not appear to be abundant in the Pecos greenstone belt east of the fault.

High abundances of zinc, niobium, antimony, and beryllium in heavymineral concentrates from small areas east and northwest of the Truchas Foaks approximately coincide with known faults and suggest that deposits containing these metals might occur in brecciated Proterozoic quartzite. 
At the south end of the study area, high abundances of tin, thorium, niobium, yttrium, tungsten, molybdenum, and lead in heavy-mineral concentrates commonly occur in areas underlain by biotite granite of the Shaggy Peak batholith and the southern end of the Santa Fe Baldy batholith. Although no deposits of these metals are known, the data suggest that the biotite granite and the quartz porphyry and aphanite are specialized rocks commonly associated with tin-producing districts.

Moderately high abundances of copper, molybdenum, and zinc were detected in many heavy-mineral concentrates from areas underlain by Paleozoic sedimentary rocks. Although no resource was identified, the data indicate that the sedimentary rocks are metalliferous.

Samples of soil (B zone) were collected at approximately 200-ft intervals along Doctor Creek (fig. 2, area 1A), along the ridge just to the north, and at other selected localities in the study area. these samples also were analyzed spectrographically. On the basis of the soil traverses, a copper deposit of unknown size and grade is inferred to exist in the Doctor Creek area.

Less than a dozen rocks, mainly gossans and one that contained visible chalcopyrite and malachite, were collected specifically as part of the geochemical survey. The purpose of these samples was to test the metal contents of specific possibly metalliferous localities that were recognized during the geologic mapping.

Walter J. Ficklin, U.S. Geological Survey, collected and analyzed 60 samples of spring and stream water at 55 sites for their radon content, measured and reported in picocuries per 1iter of radon-222 plus daughters. The purpose of his work was to provide a guide to possible uranium occurrences at selected localities on the basis of the principle that radon (a decay product of uranium 238) is carried by ground water that has passed through deposits of uranium. Springs were sampled wherever possible, because radon, being a gas, is quickly lost to the atmosphere in turbulent mountain streams. The data indicate that uranium might occur in brecciated quartzite east of the Truchas Peaks, along with zinc, niobium, antimony, and beryllium that were detected in heavy-mineral concentrates.

\section{MINING AND MINERALIZATION}

The Pecos Wilderness contains no mines and only a few scattered mineral prospects. Less than $1.5 \mathrm{mi}$ southeast of the wilderness, however, is the Pecos mine, which from 1927 to 1939 was New Mexico's largest producer of base and precious metals. The ore body is a classic volcanogenic massive-sulfide deposit (Riesmeyer, 1978). Because such deposits are known to occur in clusters in major greenstone belts elsewhere in the world, the most favorable geologic terranes near the wilderness have been explored intensively for several years. A major discovery (Mining World, 1978) near the Jones mine is one known result. Pegmatites also have been the focus of much exploration for several decades just outside the wilderness, and minor production of mica, beryl, and lithium has been reported.

\section{Tererro area}

The Pecos mine is the most notable of several properties in the study area. The deposit was discovered in 1881 , but it was not until after American Metals acquired it in 1925 that the mine became a substantial producer. 
According to available production figures, from 1927 to 1939 the mine produced about 2.3 million tons of ore that contained approximately 13 percent zinc, 4 percent lead, 0.8 percent copper, and 0.11 ounces of gold and 3.4 ounces of silver per ton. At 1978 prices the value of the ore would be more than $\$ 300$ million.

From early 1974 to around 1980, Continental 0il Co. (Conoco) explored for volcanogenic massive-sulfide deposits in the vicinity of Macho Canyon and the Jones mine, from which small high-grade shipments may have been made long ago. An important discovery by Conoco near the Jones mine has been reported by Mining World (1978). Core samples were reported to have assayed 7 percent zinc, 3 percent copper, and several ounces of silver per ton. One hole drilled by Conoco showed a thickness of $70 \mathrm{ft}$ of massive-sulfide ore containing about 3 percent copper, 0.07 percent lead, 6.9 percent zinc, and 0.6 ounce of silver and 0.072 ounce of gold per ton (Conoco, oral commun., 1978).

\section{Dalton Canyon}

In 1979-80, Santa Fe Mining, Inc., intensively explored the area of Dalton Canyon, then adjacent to a RARE II roadless area, but now well south of the established wilderness. M.S. Fulp of Santa Fe Mining, Inc., and Moench of the U.S. Geological Survey independently concluded that the rocks of the area are highly favorable for the occurrence of volcanogenic massive-sulfide deposits (Fulp, 1982; Moench and Erickson, 1980). This conclusion was borne out by the geochemical sampling, which also show the presence of abundant tungsten in possibly stratabound deposits (Moench and Erickson, 1980). Subsequently, a scheelite-bearing stratabound deposit was found by Santa $\mathrm{Fe}$ Mining, Inc. (Fulp and Renshaw, 1985), at the Blacklite prospect, which is at the site of scheelite-bearing float reported by Moench and Erickson (1980, fig. 1). The deposit is described as 5-20 ft thick, at least $1,200 \mathrm{ft}$ long (average grade not reported) and occurs along the contact between interbedded metabasalt and mafic metasedimentary rocks and sulfide-bearing felsic metat'iff and metachert. The scheelite occurs in unfoliated rock composed mainly of coarsely intergrown epidote, pale-green hornblende, and quartz (Moench and Erickson, 1980, p. 18) or epidote and actinolite with or without biotite (Filp and Renshaw, 1985, p. 67). Fulp and Renshaw (1985, p. 67) also report the occurrence of many discordant scheelite-bearing quartz veins and pods, fracture coatings, and pegmatite dikelets within mafic host rocks. These deposits are south of Dalton Canyon in the McClure septum.

\section{Pidlite pegmatite}

The Pidlite pegmatite is about $5 \mathrm{mi}$ west of Rociada in the so-called Rociada mining district. Lithium-bearing mica (lepidolite) has been the major resource in the area. The property contains numerous lithium-bearing pegmatite dikes developed by several shafts, adits, and trenches. The bodies are dikes and lenses that strike north and dip steeply. They are as much as $20 \mathrm{ft}$ thick and $150 \mathrm{ft}$ long, and are composed mainly of feldspar, quartz, and muscovite; lepidolite and muscovite are in outer zones (Jahns, 1953). According to Sheffer and Goldsmith (1969), 372 tons of lepidolite and 1.5 tons of microlite (a calcium-tantalum oxide) were shipped from the property in 1946-47. The highest concentration of tantalum in samples obtained by Sheffer and Goldsmith (1969) was 0.115 percent tantalum oxide. Sheffer and Goldsmith 
concluded that significant production of tantalum, rubidium, or beryllium from pegmatites of the area is improbable. Samples obtained by Lane during our investigation show generally less than 0.6 percent lithium.

\section{E1k Mountain pegmatite}

The Elk Mountain pegmatite mine is at an altitude of about 10,500 ft on the east side of Elk Mountain, near the southeast side of the wilderness. The area is covered by 12 claims located in 1936. The Elk Mountain mine is on the Kept Man claim and is sometimes referred to by that name. Mining began in 1942 , and 450 tons of sheet mica and 21 tons of scrap mica are estimated to have been produced through 1958 (Redmon, 1961). The pegmatites strike north and dip steeply west; the largest is about $200 \mathrm{ft} 1$ long. They are zoned, having a core of massive quartz and an outer zone of coarsely crystallized albite, microcline, quartz, and scattered sheets of muscovite. Mica shoots, typically along the boundary between the core and the outer zone, are 3-15 ft thick and have about 55 percent muscovite (Jahns, 1946).

\section{Aspen Ranch pegmatite area}

The Aspen Ranch pegmatite area is about $11 \mathrm{mi}$ northeast of Santa Fe. From 1955 through 1957, 57 claims were located in the area and in 1977 these claims were controlled by Lucky Star Mining Company. The area has been extensively bulldozed, but no production from the area has been reported. The primary mining interest has been for mica. The mica is only good for scrap and constitutes only about 1 percent of the pegmatite (Redmon, 1961).

\section{Cordova pegmatite area}

The Cordova pegmatite area, about $4 \mathrm{mi}$ southeast of Cordova, was prospected mainly in 1954-55. The area includes four major groups of claims in pegmatites. Most of the prospecting and mining was done for mica at small pits and trenches. Although most of the mica is of scrap quality, 1751 bs of sheet mica is reported to have been shipped from the Green Rock claim in 1956 (Redmon, 1961). About 6001 bs of beryl is reported to have been recovered from the Rockin Chair claim (Redmon, 1961).

\section{ASSESSMENT OF MINERAL RESOURCES}

Moderate mineral resource potential is assigned to less than $3 \mathrm{sq} \mathrm{mi}$ within the Pecos Wilderness, or slightly less than 1 percent of the area of the established wilderness. The most important resources are identified just. south of the Pecos Wilderness

Area $1 \mathrm{~A}$ has moderate potential for copper, lead, zinc, silver, and gold in massive-sulfide deposits associated with transition-facies metavolcanic rocks.

Area $1 B$ has high potential for the same metals in similar volcanogenic deposits associated with vent-facies metavolcanic rocks. In both areas, deposits may be difficult to find under thick sedimentary cover.

Area 2 has moderate potential for copper, lead, zinc, gold, and silver in stratabound massive-sulfide deposits. Although some analyses of heavy-mineral concentrates yielded high values for tin and tungsten in addition to copper, lead, silver, and bismuth, some of the heavy minerals may have come from west. 
of the Pecos-Picuris fault, where high abundances of tin and tungsten are more common.

Area 3 has moderate potential for copper, lead, zinc, gold, and silver in stratabound massive-sulfide deposits. Potential is considered lower than that of area 1 because the area of somewhat favorable rocks is smaller and evidence of mineralization was not found in bedrock.

Area 4 has moderate potential for copper, lead, zinc, gold, and silver in stratabound massive-sulfide deposits. Exposed metavolcanic rocks are distalfacies, however, and the resource potential is considered to be lower than those of areas $1 \mathrm{~A}$ and 3 .

Area 5 has high potential for copper, lead, zinc, gold, and silver in stratabound massive-sulfide deposits, and for tungsten in stratabound scheelite deposits and possibly in crosscutting scheelite-bearing veins and pods.

Area 6 has high potential for the occurrence of tungsten in possible stratabound deposits and (or) in crosscutting veins and pods. The environment is peripheral to the Dalton volcanic center.

Area 7 has moderate potential for tungsten and molybdenum in possible stratabound deposits and (or) crosscutting veins and pods.

Area 8 includes two areas that have moderate potential for mica in pegmatite dikes and lenses.

Area 9 has moderate potential for beryllium in beryl-bearing pegmatite dikes and lenses.

Area 10 has moderate potential for lithium and possibly tantalum in pegmatite dikes and lenses. Sheffer and Goldsmith (1969) found that tantalum at the Pidlite mine occurs only in subeconomic quantities.

Area 11 has unknown potential for zinc, niobium, antimony, minor beryllium, and possibly uranium in brecciated quartzite along and near the Jicarilla fault. No occurrences in bedrock are known, but attention is directed to the area by the geochemical data and a possibly favorable bedrock setting.

Area 12 has unknown potential for niobium and subordinate antimony possibly in brecciated quartzite east of Pecos-Picuris fault and along strike with an unnamed fault. No occurrences in bedrock are known, but attention is directed to the area by geochemical data and a geologic setting that is similar to that of area 11 .

Area 13 has unknown potential for tin, thorium, niobium, and possibly tungsten and molybdenum in disseminated deposits or greisen veins related to biotite granite of the Shaggy Peak batholith and biotite granite and quartz porphyry and aphanite at the southern edge of the Santa Fe Baldy batholith. No occurrences in bedrock are known but attention is directed to the area by geochemical data which indicate that the granites may be a specialized typ? characteristic of many tin-bearing districts. The most favorable setting for the occurrence of tin-bearing greisen deposits is the contact zone between stratified metamorphic rocks of the McClure septum and quartz porphyry and aphanite of the Santa Fe Baldy batholith.

With the possible exception of uranium in area 11 , no potential is recognized within the Pecos Wilderness for energy-related materials, such as oil, gas, coal, or geothermal resources. 


\section{REPERENCES CITED}

Bowring, S.A., and Condie, K.C., 1982, U-Pb zircon ages from northern and central New Mexico: Geological Society of America, Abstracts with Programs, v. 14 , no. 6 , p. 304.

Erickson, M.S., Sutley, S.J., and Moench, R.H., 1986, Analytical results and sample locality map of stream-sediment, heavy-mineral-concentrate, soil, and rock samples from the Pecos Wilderness, Santa Fe, San Miguel, Mora, Rio Arriba, and Taos Counties, New Mexico: U.S. Geological Survey Open-File Report 86-171, 113 p.

Fulp, M.S., 1982, Precambrian geology and mineralization of the Dalton Canyon volcanic center, Santa Fe County, New Mexico: Albuquerque, University of New Mexico, M.S. thesis, 199 p.

Fulp, M.S., and Renshaw, J.L., 1985, Volcanogenic-exhalative tungsten mineralization of Proterozoic age near Santa Fe, New Mexico, and implications for exploration: Geology, v. 13, no. 1, p. 66-69.

Jahns, R.H., 1946, Mica deposits of the Petaca district, Rio Arriba County, New Mexico: New Mexico Bureau of Mines and Mineral Resources Bulletin 25,294 p.

1953, The genesis of pegmatites; II. Quantitative analysis of lithiumbearing pegmatite, Mora County, New Mexico: American Mineralogist, v. 38 , p. 1078-1112.

Lane, M.E., 1980, Mines, prospects, and mineralized areas in the Pecos Wilderness and adjacent areas; Chap. $C$ in Mineral resources of the Pecos Wilderness and adjacent areas, Santa Fe, San Miguel, Mora, Rio Arriba, and Taos Counties, New Mexico: U.S. Geological Survey Open-File Report 80-382, p. 69-103.

Mining World, 1978, Conoco discovers massive sulphides in Pecos Mountains: Mining World, v. 31 , no. 2, p. 76 .

Moench, R.H., and Erickson, M.S., 1980, Occurrence of tungsten in the Sangre de Cristo Range near Santa Fe, New Mexico--Possible stratabound scheelite peripheral to favorable settings for volcanogenic massive-sulfide deposits: U.S. Geological Survey Open-File Report 80-1162.

Moench, R.H., Grambling, J.A., and Robertson, J.M., 1988, Geologic map of the Pecos Wilderness, Santa Fe, San Miguel, Mora, Rio Arriba, and Taos Counties, New Mexico: U.S. Geological Survey Miscellaneous Field Studies Map MF-1921-B.

Moench, R.H., and Robertson, J.M., 1980, Geology of the Pecos Wilderness and adjacent areas; Chap. A in Mineral resources of the Pecos Wilderness and adjacent areas, Santa Fe, San Miguel, Mora, Rio Arriba, and Taos

Counties, New Mexico: U.S. Geological Survey Open-File Report 80-382, A, p. 6-41.

Moench, R.H., Robertson, J.M., and Sutley, J.S., 1980, Geologica1, geochemical, and geophysical evaluation of the mineral resources of the Pecos Wilderness and adjacent areas; Chap. B in Mineral resources of the Pecos Wilderness and adjacent areas, Santa Fe, San Miguel, Mora, Rio Arriba, and Taos Counties, New Mexico: U.S. Geological Survey Open-File Report 80-382, p. 42-68.

Moench, R.H., Sutley, S.J., and Erickson, M.S., 1988, Geochemical maps of the Pecos Wilderness, Santa Fe, San Miguel, Mora, Rio Arriba, and Taos Counties, New Mexico: U.S. Geological Survey Miscellaneous Field Studies Map MF-1921-C. 
Redmon, D.E., 1961, Reconnaissance of selected pegmatite districts in northcentral New Mexico: U.S. Bureau of Mines Circular 8013, 79 p.

Riesmeyer, W.D., 1978, Precambrian geology and ore deposits of the Pecos mining district, Santa Fe and San Miguel Counties, New Mexico: Albuque rque, University of New Mexico, M.S. thesis, 215 p.

Riesmeyer, W.D., and Robertson, J.M., 1979, Precambrian geology and ore deposits of the Pecos mine, San Miguel County, New Mexico; in Santa Fe country: New Mexico Geological Society Guidebook, 39th Annual Field Conference, p. 175-179.

Robertson, J.M., and Moench, R.H, 1979, The Pecos greenstone belt--A Proterozoic volcano-sedimentary sequence in the southern Sangre de Cristo Mountains, New Mexico; in Santa Fe country: New Mexico Geological Society Guidebook, 30th Annual Field Conference, p. 165-173.

Sheffer, H.W., and Goldsmith, L.A., 1969, Tantalum project, Rociada, New Mexico: New Mexico Bureau of Mines and Mineral Resources, Mineral Resources Report 2, 15 p.

U.S. Geological Survey, U.S. Bureau of Mines, and New Mexico Bureau of Mires and Mineral Resources, 1980, Mineral resources of the Pecos Wilderness and adjacent areas, Santa Fe, San Miguel, Mora, Rio Arriba, and Taos Counties, New Mexico: U.S. Geological Survey Open-File Report 80-382, 117 p. 
, 